\title{
Human immature germ cells and ejaculated spermatozoa contain aromatase and oestrogen receptors
}

\author{
S Lambard ${ }^{1}$, I Galeraud-Denis ${ }^{1,2}$, PTK Saunders ${ }^{3}$ and S Carreau ${ }^{1}$ \\ ${ }^{1}$ USC-INRA EA 2608, University of Caen, Caen, France \\ ${ }^{2}$ Department of Genetics and Reproduction, CHU, Caen France \\ ${ }^{3}$ MRC Human Reproductive Sciences Unit, 49 Little France Cresent, Edinburgh EH16 4SB, UK \\ (Requests for offprints should be addressed to S Carreau, Biochimie-IRBA, esplanade de la Paix, 14032 Caen-cedex, France; \\ Email: carreau@ibba.unicaen.fr)
}

\begin{abstract}
It is now well established that oestrogens play a part in germ cell function. These hormones are synthesised by the cytochrome P450 aromatase (P450 arom) and act via two kinds of receptor (ER $\alpha$ and $E R \beta)$. Although the presence of aromatase and oestrogen receptors in mammalian testis is now well documented, the localisation of these proteins in human germ cells is not yet clear. The primary purpose of the current study was to look for the expression of aromatase and oestrogen receptors in human germ cells. Human immature germ cells were collected from semen samples with an excess of rounds cells $(>20 \%)$ and purified spermatozoa were obtained after sedimentation on a discontinuous PureSperm gradient. Expression of aromatase and oestrogen receptors was determined by RT-PCR with specific primers, and by Western blot using monoclonal antibodies. RT-PCR products for aromatase, ER $\alpha$ and ER $\beta$ were amplified from total RNA isolated from human germ cells and spermatozoa. We identified an $E R \alpha$ isoform variant that lacks exon 4 in human germ cells and visualised P450 arom as a single band of $49 \mathrm{kDa}$ in germ cells, as we have already reported for human ejaculated spermatozoa. By Western blot, we identified two proteins for $\mathrm{ER} \beta$ at $\sim 50$ and $\sim 60 \mathrm{kDa}$, which could correspond to the long and short forms of ER $\beta$ formed from the use of alternative start sites. In human ejaculated spermatozoa, ER $\beta$ protein was not detected, even though we could amplify mRNA. Using Western blot analysis and a monoclonal antibody specific for $\mathrm{ER} \alpha$, we detected two proteins in human immature germ cells: one of the expected size $(66 \mathrm{kDa})$ and a second one of $46 \mathrm{kDa}$. In mature spermatozoa, only the $46 \mathrm{kDa}$ band was observed and we speculate it may be related to the ER $\alpha$ isoform lacking exon I. In conclusion, we have identified P450 arom and ER proteins (full-length and variant) in human germ cells. Further studies are now required to elucidate the mechanism of action of oestrogens on human male germ cells, in terms of both genomic and 'non-genomic' pathways.
\end{abstract}

Journal of Molecular Endocrinology (2004) 32, 279-289

\section{Introduction}

The irreversible conversion of androgens into oestrogens is catalysed by cytochrome $\mathrm{P} 450$ aromatase ( $\mathrm{P} 450$ arom), a product of a unique gene called Cyp19 (Simpson et al. 2002), which is located in the endoplasmic reticulum membrane. Although oestrogens have been considered to be female hormones, it is now well established that they have an important role in male reproduction. In adult males, Leydig cells have been considered for a long time as the major source of oestrogens, whereas Sertoli cells synthesise oestradiol in prepubertal males (Papadopoulos et al. 1986, Carreau et al. 1988). However, in the past decade there has been a growing body of evidence that germ cells could also synthesise oestrogens. In fact, the presence of aromatase has been demonstrated in germ cells of a great number of species (Nitta et al. 1993, Janulis et al. 1998, for review see Carreau et al. 1999). 
In adult human testis, aromatase was previously immunolocalised to Leydig cells, but not Sertoli cells (Payne et al. 1976, Brodie et al. 2001). However, recently, aromatase has also been immunolocalised to the cytoplasm surrounding elongated spermatids (Turner et al. 2002), and we and others have reported the presence of aromatase in human ejaculated spermatozoa (Aquila et al. 2002, Lambard et al. 2003).

The effects of oestrogens on target tissues are mediated by specific receptors. Until now, two oestrogen receptors (ER) have been cloned: ER $\alpha$ (Green et al. 1986) and $\operatorname{ER} \beta$ (Kuiper et al. 1996), both of which belong to the superfamily of nuclear hormone receptors. Numerous isoforms/variants have also been identified. Almost all these transcripts are generated by skipping of one or more exons, duplication or deletion of one or more exons, alternative usage of the $5^{\prime}$-untranslated exons or alternative usage of the coding exons (Hirata et al. 2003).

The presence of ER in the male reproductive tract of a large number of mammalian species is now well documented (O'Donnell et al. 2001). However, the distribution of the two receptor subtypes does not seem to be similar between species. In adult rodent testis, Leydig cells are immunopositive for ER $\alpha$ (Zhou et al. 2002), whereas caprine Leydig cells are immunonegative (Goyal et al. 1997). ER $\beta$ transcript was not found in the germ cells of adult rat testis (Mowa \& Iwanaga 2001), but other studies have reported expression of $\mathrm{ER} \beta$ (protein and mRNA) in the germ cells of rodent testis (Saunders et al. 1998, Van Pelt et al. 1999, Zhou et al. 2002).

In humans, data about the localisation of ER in seminiferous tubules are also controversial. Pelletier \& El-Alfy (2000) did not observe any tubular labelling, for either ER $\beta$ or ER $\alpha$. In contrast, Mäkinen et al. (2001) and Saunders et al. (2001) have detected $\operatorname{ER} \beta$ immunoreactivity in spermatogonia, spermatocytes and early developing spermatids, but no staining in elongated spermatids and mature spermatozoa. No immunoexpression of $\mathrm{ER} \alpha$ was detected in testes. Pentikaïnen et al. (2000) have demonstrated the presence of ER $\alpha$ in human germ cells and Durkee et al. (1998) and Luconi et al. (1999) have reported the existence of $\mathrm{ER} \alpha$ in human ejaculated spermatozoa. To clarify these data further, the aim of this study was to determine if adult human testicular germ cells and ejaculated spermatozoa are potential sources, targets, or both, of oestrogens. For that purpose, we looked for the expression of aromatase, $\mathrm{ER} \alpha$ and $\operatorname{ER} \beta$, as indicated by the presence of both transcripts and proteins, in human immature germ cells and ejaculated spermatozoa.

\section{Materials and methods}

\section{Human semen sample preparation}

Sperm samples $(n=18)$ were obtained from healthy donors (mean age $32 \cdot 17 \pm 3.03$ years) by masturbation after 3 days of sexual abstinence and allowed to liquefy for $30-60 \mathrm{~min}$ at room temperature before processing. Informed patient consent was obtained for the use of sperm samples in this study. The selected specimens had normal semen parameters according to the World Health Organisation guidelines (1999). Samples with more than $1 \cdot 10^{6}$ round cells $/ \mathrm{ml}$ were excluded. A spermocytogram (analysis of sperm characteristics: volume, viscosity and $\mathrm{pH}$ of semen; number, mobility, vitality and morphology of spermatozoa) was performed in order to eliminate samples with cytoplasmic droplets. The liquefied semen samples were fractionated on discontinuous PureSperm gradient (JCD, Lyon, France) consisting of four successive layers with the following densities: 95, 76, 57 and $47 \cdot 5 \%$. A microscopic examination of the sperm-enriched fractions obtained (95\% layer) was performed to control the quality of the preparations (motility, survival and morphology). The purity of this fraction (observed under microscope) was close to $100 \%$, when compared with non-purified sperm (Fig. $1 a$ and $b$ ).

Human leucocytes were obtained from healthy donors. Human granulosa cells (positive aromatase control) were collected from human follicular fluid from preovulatory follicles in the In Vitro Fertilisation Genter (CHRU Clémençeau, Caen, France).

\section{Isolation of human germ cells}

Semen samples $(n=4)$ with more than $20 \%$ of round cells (mainly germ cells) were selected (Fig. 1c). Although these samples showed a high number of round cells, the spermatic parameters were not altered. The liquefied semen samples were fractionated on discontinuous PureSperm gradient in order 
A
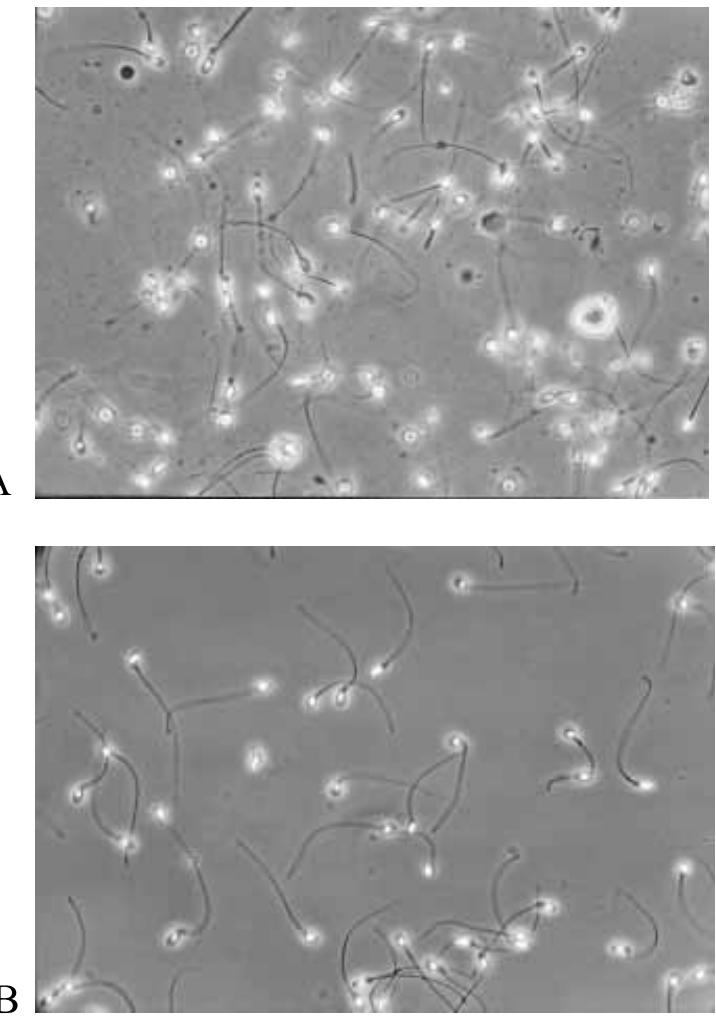

$\mathrm{C}$

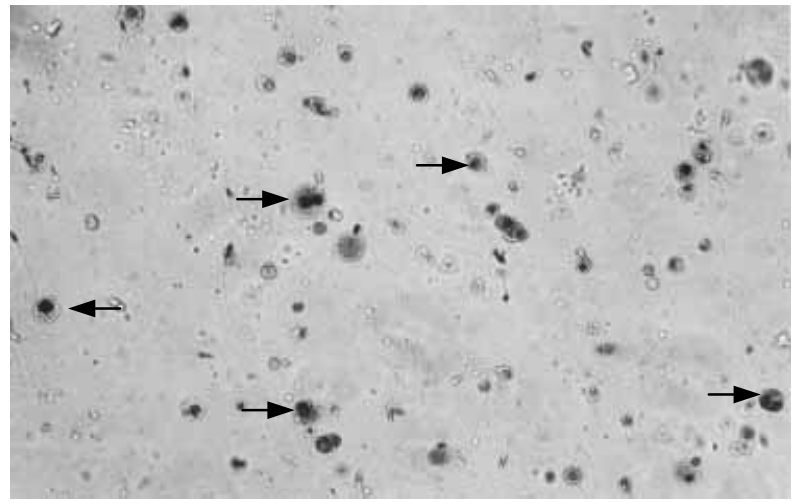

$\mathrm{D}$

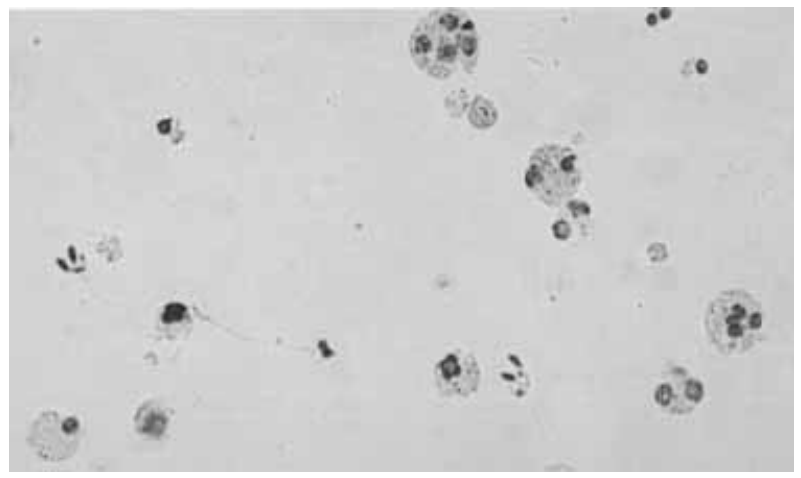

Figure 1 Microscopic examination of semen. (a) Human spermatozoa before purification on a discontinuous gradient (original magnification $\times 400$ ). (b) Human spermatozoa isolated from the $95 \%$ Puresperm fraction (original magnification $\times 400$ ). (c) Human semen with an excess of round cells (arrows) (original magnification $\times 200$ ). (d) Human immature germ cells isolated from the $47.5 \%$ Puresperm fraction (original magnification $\times 200$ ).

to eliminate the majority of spermatozoa. Round cells were collected from the $47 \cdot 5 \%$ layer and washed twice with Earle's medium (Fig. 1d).

\section{RNA extraction}

Total RNAs from purified sperm fractions and granulosa cells were extracted using the guanidinium thiocyanate-phenol-chloroform method (Chomczynski \& Sacchi 1987). Briefly, after centrifugation the cell pellets were homogenized on ice in a $1 \mathrm{M}$ Tris buffer containing guanidinium thiocyanate (4 M). The RNA was then isolated with a phenol-chloroform-isoamylic acid solution. It was precipitated twice from the aqueous phase with isopropanol, washed with $75 \%$ ethanol, dried on speed-vac and dissolved in diethyl pyrocarbonatetreated water and then stored at $-80^{\circ} \mathrm{C}$. The purity of RNA samples was checked spectroscopically by measuring the optic density at 260 and $280 \mathrm{~nm}$ and by evaluating the ratio $260 / 280 \mathrm{~nm}$.

\section{RT-PCR assay}

Four hundred nanograms total RNA were reversetranscribed to first-strand cDNA as follows: $1 \mathrm{~h}$ at $37^{\circ} \mathrm{C}$ with 200 IU M-MLV-RT (Promega, Charbonnières, France), $500 \mu \mathrm{M}$ dNTP, $0 \cdot 2 \mu \mathrm{g}$ oligo-dT (12-18 mers) and 24 IU RNasin in a final volume of $10 \mu \mathrm{l}$, then $5 \mathrm{~min}$ at $94^{\circ} \mathrm{C}$.

The cDNAs were further amplified by PCR using selected oligonucleotides. PCR was performed in the presence of $1.5 \mathrm{mM} \mathrm{MgCl} 2,200 \mu \mathrm{M}$ dNTP, 1.5 IU Taq polymerase and $50 \mathrm{pmol}$ forward and reverse primers (Life Technology) in a final volume of $50 \mu \mathrm{l}$. The applied PCR primers and the expected lengths of the resulting PCR products are shown in Table 1 . All primers were chosen in different exons in order to eliminate any potential contamination by genomic DNA; the cycle profiles used are described in Table 2.

Contamination by leucocytes and Sertoli cells in our germ cell preparations was assessed by 
Table 1 Oligonucleotide sequences used for RT-PCR

\begin{tabular}{|c|c|c|c|}
\hline & Sequence $\left(5^{\prime}-3^{\prime}\right)$ & $\begin{array}{l}\text { Size of } \\
\text { PCR } \\
\text { product } \\
\text { (bp) }\end{array}$ & Reference \\
\hline $\begin{array}{l}\text { Gene } \\
\text { Aromatase }\end{array}$ & $\begin{array}{l}\text { 5'-TGAATATTGGAAGGATGCACAGAC-3' } \\
\text { 5'-TGGAATCGTCTCAGAAGTGTAACGAG-3' }\end{array}$ & 189 & Lambard et al. 2003 \\
\hline CD45 & $\begin{array}{l}\text { 5'-TGCAGATGCCTACCTTAATGC-3' } \\
\text { 5'-CACATTGCAGCACTTCCATT-3' }\end{array}$ & 844 & $\begin{array}{l}\text { Ralph et al. } 1987 \\
\text { GenBank accession No. Y00062.1 }\end{array}$ \\
\hline c-kit & $\begin{array}{l}\text { 5'-AGTACATGGACATGAAACCTGG-3' } \\
\text { 5'-GATTCTGCTCAGACATCGTCG-3' }\end{array}$ & 780 & de los Santos et al. 1998 \\
\hline $\mathrm{ER} \alpha$ & $\begin{array}{l}\text { 5'-GACTATGCTTACGGCTACCATT-3' } \\
\text { 5'-TGGTTCCTGTCCAAGAGCAAGTTA-3' }\end{array}$ & 674 & Hillier et al. 1998 \\
\hline $\begin{array}{l}\text { ER } \alpha \text { exon-1- } \\
\text { deleted }\end{array}$ & $\begin{array}{l}\text { 5'-CCGGTTTCTGAGCCTTCTG-3' } \\
\text { 5'-TCCTTGGCAGATTCCATAGC-3' }\end{array}$ & 264 & $\begin{array}{l}\text { Green et al. } 1986 \\
\text { GenBank accession No. X03635.1 }\end{array}$ \\
\hline $\mathrm{ER} \beta$ & $\begin{array}{l}\text { 5'-TAGTGGTCCATCGCCAGTTATCAC-3' } \\
\text { 5'-GCACTTCTCTGTCTCCGCACAA-3' }\end{array}$ & 438 & Hillier et al. 1998 \\
\hline GAPDH & $\begin{array}{l}\text { 5'-TGAACGGGAAGCTCACTGGCATGGCCTT-3' } \\
\text { 5'-GTGTGGTGGGGGACTGAGTGTGGCAGGGAC-3' }\end{array}$ & 431 & Lambard et al. 2003 \\
\hline Protamines-2 & $\begin{array}{l}\text { 5'-GGATCCACAGGCGGCAGCATCGCT-3' } \\
\text { 5'-GCATGTTCTCTTCCTGGTTCTGCA-3' }\end{array}$ & 103 & Siffroi and Dadoune 2001 \\
\hline SCF & $\begin{array}{l}\text { 5'-AACCCTCAAATATGTCCCCG-3' } \\
\text { 5'-CTGCCCTTGTAAGACTTGGC-3' }\end{array}$ & $\begin{array}{l}584 \text { or } \\
500\end{array}$ & Teyssier-Le Discorde et al. 1999 \\
\hline
\end{tabular}

amplifying CD45 and SCF transcripts respectively; c-kit (a germ cell marker) was used to verify the presence of germ cells.

For all PCR amplifications, negative (water only) and positive controls were included. All cDNA fragments were run on a $1 \cdot 5 \%$ agarose gel stained with ethidium bromide and visualised under UV transillumination.

Table 2 Cycling conditions for the different sets of pairs

\section{Cycle profile}

\section{Gene}

Aromatase $\quad 95^{\circ} \mathrm{C} / 1 \mathrm{~min}, 60^{\circ} \mathrm{C} / 1 \mathrm{~min}, 72^{\circ} \mathrm{C} / 1.5 \mathrm{~min}$

CD45

C-kit

$\mathrm{ER} \alpha$

ER $\alpha$ exon 1

ER $\beta$

GAPDH

Protamines-2

SCF $95^{\circ} \mathrm{C} / 45 \mathrm{~s}, 60^{\circ} \mathrm{C} / 45 \mathrm{~s}, 72^{\circ} \mathrm{C} / 1 \mathrm{~min}$ $95^{\circ} \mathrm{C} / 1 \mathrm{~min}, 52^{\circ} \mathrm{C} / 1 \mathrm{~min}, 72^{\circ} \mathrm{C} / 1 \mathrm{~min}$ $95^{\circ} \mathrm{C} / 45 \mathrm{~s}, 60^{\circ} \mathrm{C} / 45 \mathrm{~s}, 72^{\circ} \mathrm{C} / 2 \mathrm{~min}$ $95^{\circ} \mathrm{C} / 1 \mathrm{~min}, 58^{\circ} \mathrm{C} / 1 \mathrm{~min}, 72^{\circ} \mathrm{C} / 1.5 \mathrm{~min}$ $95^{\circ} \mathrm{C} / 45 \mathrm{~s}, 60^{\circ} \mathrm{C} / 45 \mathrm{~s}, 72^{\circ} \mathrm{C} / 2 \mathrm{~min}$ $95^{\circ} \mathrm{C} / 1 \mathrm{~min}, 60^{\circ} \mathrm{C} / 1 \mathrm{~min}, 72^{\circ} \mathrm{C} / 1 \mathrm{~min}$ $95^{\circ} \mathrm{C} / 45 \mathrm{~s}, 56^{\circ} \mathrm{C} / 45 \mathrm{~s}, 72^{\circ} \mathrm{C} / 45 \mathrm{~s}$ $95^{\circ} \mathrm{C} / 1 \mathrm{~min}, 56^{\circ} \mathrm{C} / 1 \mathrm{~min}, 72^{\circ} \mathrm{C} / 1 \mathrm{~min}$

\section{DNA sequence analysis}

The RT-PGR products were extracted from the agarose gel by using a gel band purification kit (Amersham Biosciences). The purified DNAs were amplified and then sequenced using a DNA sequencing kit (ABI Prism BigDye Terminator Cycle Sequencing Ready Reaction) and procedure for fluorescence-based DNA sequencing with Taq polymerase (Applied Biosystems).

\section{Protein extraction}

The spermatozoa isolated from the 95\% PureSperm layer and the mixture of germ cells were washed twice with Earle's medium. The pellets were resuspended in lysis buffer $[100 \mathrm{mM}$ Tris-HCl pH 7•4, 20\% glycerol, $150 \mathrm{mM} \mathrm{KCl,}$ $1 \mathrm{mM}$ dithiothreitol, $1 \mathrm{mM}$ EDTA, containing one protease inhibitor tablet (Roche)/10 ml buffer]. Samples were homogenised and sonicated and protein concentrations determined using Bradford's assay (1976). 


\section{Western blot}

Five microlitres denaturing loading buffer $(20 \%$ sucrose, 5\% SDS, 5\% $\beta$-mercaptoethanol, 0.075\% bromophenol blue) were added to aliquots of protein and boiled for $10 \mathrm{~min}$. The samples were electrophoresed at $30 \mathrm{~mA}$ for $2 \mathrm{~h}$ on $10 \%$ SDS-polyacrylamide gel using a running buffer consisting of $25 \mathrm{mM}$ Tris, $192 \mathrm{mM}$ glycine $\mathrm{pH} 8 \cdot 3$, $0 \cdot 1 \%$ SDS and the proteins were then transferred onto nitrocellulose enhanced chemiluminescence (ECL) membranes (Amersham) in a transfer buffer (Tris $20 \mathrm{mM}$, glycine $150 \mathrm{mM}, 20 \%$ methanol) at $200 \mathrm{~V}$ for $45 \mathrm{~min}$. The membranes were blocked for $2 \mathrm{~h}$ at room temperature in $4 \%$ non-fat dried milk in $0 \cdot 1 \%$ Tween $20,10 \mathrm{mM}$ Tris and $15 \mathrm{mM}$ $\mathrm{NaCl}$ pH 7·4 (TTBS), incubated overnight with the primary antibody [anti-aromatase 1:500 (Code MCA 2077 Serotec UK), anti-ER $\alpha$ 1:100 (SantaCruz, France) or anti-ER $\beta$ 1:250 (Code EMR02, Novocastra, Newcastle, UK)], all of which were diluted in TTBS containing $2 \%$ non-fat dried milk. The antigen-antibody complexes were detected by incubation of the membranes for $90 \mathrm{~min}$ with appropriate secondary antibodies (sheep antimouse; Amersham) and developed using the ECL Plus Western blotting detection system (Amersham).

Proteins extracted from human granulosa cells were used as positive control.

\section{Results}

\section{Characterisation of germ cells}

In order to eliminate any contamination of samples by leucocytes, we looked for the white blood cell specific CD45 transcript in the preparations of round cells; samples containing detectable levels of CD45 transcripts were excluded. We were also unable to amplify Sertoli cell factor (SCF) mRNA (specific for Sertoli cells) in our germ cell preparations. Conversely, all isolated round cells contained transcripts for c-kit, which is a positive control for testicular germ cells (Fig. 2a). In fact, it has been demonstrated that c-kit is expressed in premeiotic and meiotic germ cells of the mouse (Albanesi et al. 1996), but this result does not exclude the presence of post-meiotic germ cells in our human samples.

No detectable levels of mRNA coding either CD45 or c-kit were found in purified semen samples (Fig. 2b).

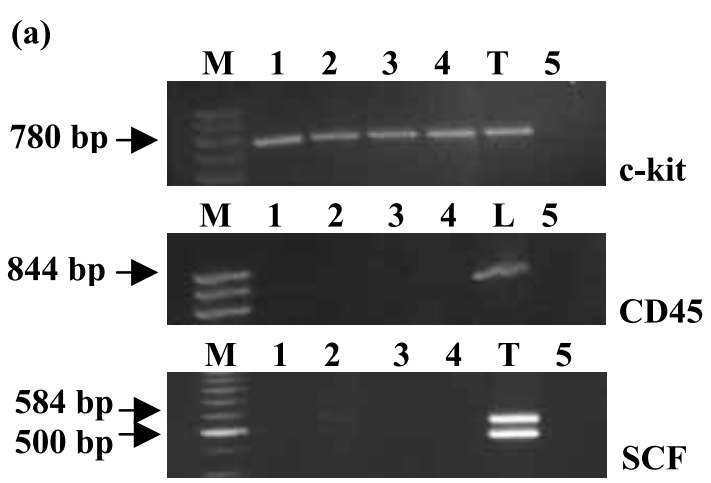

(b)

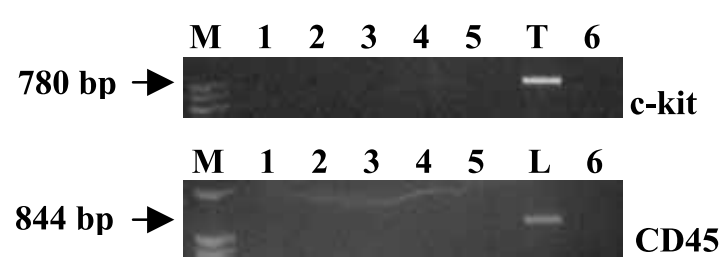

Figure 2 Agarose gel showing the PCR products of c-kit, CD45 and SCF. (a) RNA extracted from human germ cells (lanes 1-4), human testis $(T)$ and human leucocytes (L). RNA was omitted in lane 5. M, DNA ladder (100 bp). Two bands were observed in the RT-PCR product for SCF, one at $584 \mathrm{bp}$ and the other at $500 \mathrm{bp}$, assigned respectively to transcripts encoding the soluble and membrane forms of SCF. (b) RNA extracted from human spermatozoa isolated from the 95\% PureSperm fraction (lanes 1-5), human testis ( $T$ ) and human leucocytes $(\mathrm{L})$. RNA was omitted in lane 6. $\mathrm{M}$, molecular mass standard (100 bp).

\section{Detection of aromatase and oestrogen receptor transcripts}

We looked for the expression of aromatase and oestrogen receptor transcripts in human germ cells. The PGR amplification was carried using 30 cycles for all transcripts. Aromatase, oestrogen receptors (both types) and GAPDH mRNA were present in four different preparations of human germ cells (Fig. 3). There was no detectable signal in samples processed without reverse transcriptase (data not shown). We observed two bands for ER $\alpha$ transcripts, one at the expected size and another at a smaller size. The PCR product corresponding to the smaller band was sequenced and found to be an $\mathrm{ER} \alpha$ isoform that lacks exon IV (Fig. 4).

After 35 cycles of amplification, we detected both types of oestrogen receptor mRNA in purified semen samples $(n=9)$ (Fig. 5), in addition to the 

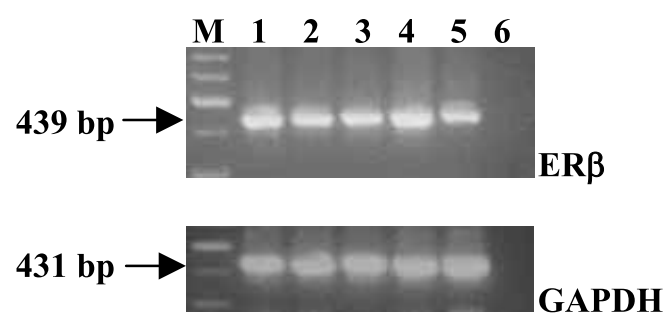

$\begin{array}{lllllll}6 & 1 & 2 & 3 & 4 & 5 & M\end{array}$

$\mathbf{E R} \alpha$

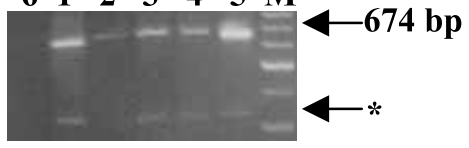

Aromatase

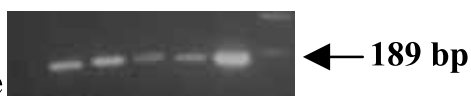

Figure 3 Analyses of ER $\beta$, ER $\alpha$, cytochrome P450 aromatase and GAPDH RT-PCR products in human germ cells after separation on 1.5\% agarose gels. Lanes 1-4: RNA extracted from human germ cells; lane 5: RNA extracted from granulosa cells; lane 6: water instead of RNA. Arrows indicate the PCR products and the expected size of amplified fragments. *An unexpected PCR product for ER $\alpha$. M, DNA ladder (100 bp).

aromatase transcripts. A strong signal was obtained when protamine- 2 mRNA was amplified. For each sample, when a control was added without the reverse transcription step, no signal was detected.

\section{Presence of aromatase and oestrogen receptor proteins}

Western blot using an antibody against human P450 arom revealed a positive signal having a molecular mass of $49 \mathrm{kDa}$ in protein extracted from 'mixed' germ cells (Fig. 6). This band migrated a little behind the $53 \mathrm{kDa}$ aromatase protein detected in human granulosa cells, as we have already described in human ejaculated spermatozoa (Lambard et al. 2003). Western
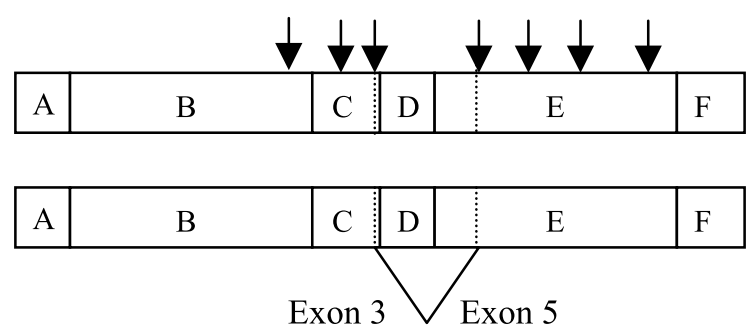

GAAAGGTGGCTTT

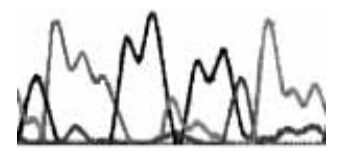

Figure 4 Schematic representation of the exon-4-deleted ER $\alpha$ isoform aligned to the wild-type ER $\alpha$. Arrows indicate exon boundaries. Wild-type ER $\alpha$ contains eight different exons coding for a protein divided into structural domains $(A-F)$. The DNA-binding domain is located in region $\mathrm{C}$, whereas the ligand-binding hormone is located in region $\mathrm{E}$. The domain $\mathrm{D}$, which is deleted in this $\mathrm{ER} \alpha$ variant, represents the hinge region. analysis of human isolated germ cells showed a signal for both ER $\beta$ and ER $\alpha$ (Fig. 6). Using an antibody specific to the C-terminal of full-length $\mathrm{ER} \beta$, we detected two bands for $\mathrm{ER} \beta$ in isolated human germ cells, one at $\sim 60 \mathrm{kDa}$ and a weaker one at $\sim 50 \mathrm{kDa}$ (Fig. 6). In spite of the presence of $\mathrm{ER} \beta \mathrm{mRNA}$ in human spermatozoa, we were unable to find the protein (data not shown). Incubation of granulosa cell samples with our ER $\beta$ antibody that had been preabsorbed with the recombinant protein did not result in detection of any protein (data not shown).

Using an antibody directed against the C-terminal region of $\mathrm{ER} \alpha$, we also detected two bands in human germ cells, one at $66 \mathrm{kDa}$ and the other at $46 \mathrm{kDa}$ (Fig. 6). In human spermatozoa, we only detected a protein at $46 \mathrm{kDa}$ (Fig. 7). The $66 \mathrm{kDa}$ band corresponds to the classic reported

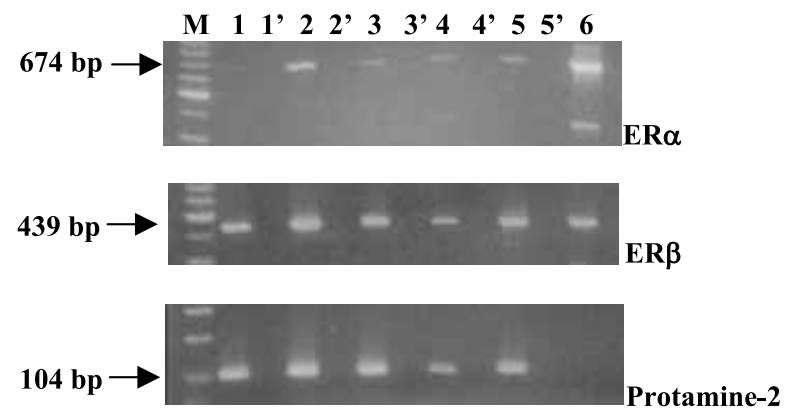

Figure 5 Analyses of $\mathrm{ER} \alpha, \mathrm{ER} \beta$ and protamine-2 RT-PCR products in human purified spermatozoa after separation on $1.5 \%$ agarose gels. Lanes 1-5: RNA extracted from human spermatozoa isolated from the 95\% PureSperm fraction; lane 6: RNA extracted from granulosa cells. M, DNA ladder (100 bp ladder). Arrows indicate the PCR products and the expected size of amplified fragments. No reverse transcriptase was added in RT-PCR reactions for products loaded in lanes 1 ' to 5 '. 


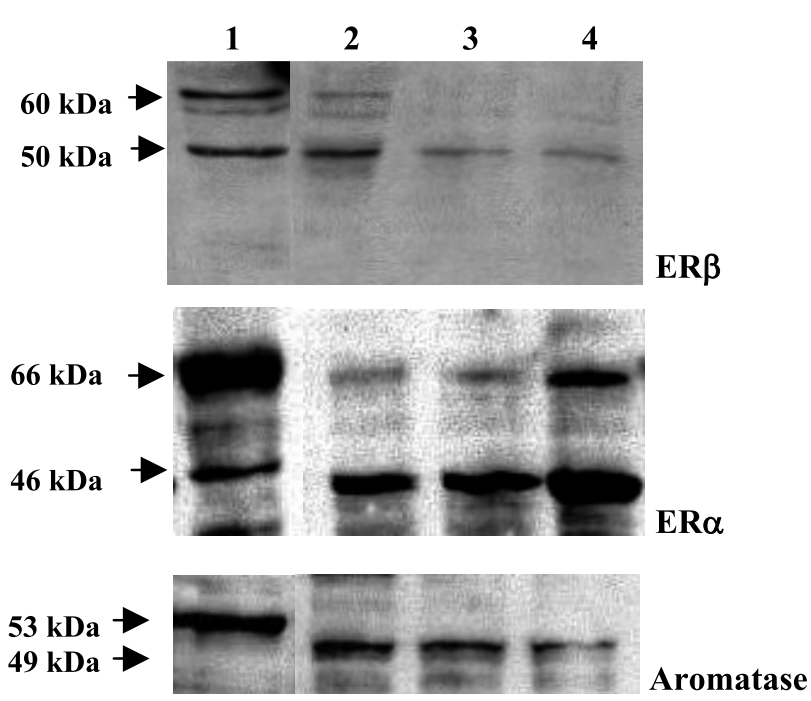

Figure 6 Western blot analysis of $\mathrm{ER} \beta, \mathrm{ER} \alpha$ and cytochrome P450 aromatase proteins in human isolated germ cells. Total cellular proteins were extracted from human granulosa (lane 1, used as a positive control) and human germ cells (lanes 2-4); $30 \mu \mathrm{g}$ of protein were loaded in each lane. Molecular masses $(\mathrm{kDa})$ are indicated on the left of the blot.

molecular mass of human ER $\alpha$, whereas the $46 \mathrm{kDa}$ band could correspond to the isoform that lacks exon I (Flouriot et al. 2000).

As our PGR primers for ER $\alpha$ were located in exon 2 and in exon 6 , we were able to amplify the wild-type and distinguish this form from the exon-4-deleted variant of ER $\alpha$. However, using these primers we can not distinguish between the wild-type and exon-1-deleted variant. Therefore, we also performed RT-PCR using primers flanking exon 1. It has been reported that this truncated transcript results from splicing of the 5'UTR variant exon $\mathrm{E}$ or $\mathrm{F}$ directly to exon 2 (Flouriot et al. 2000), so we chose a primer located in exon 2 and

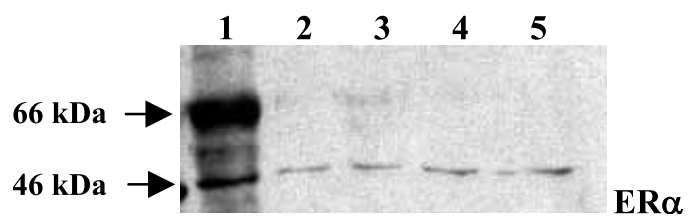

Figure 7 Western blot analysis of ER $\alpha$ protein in human spermatozoa. Total cellular proteins were extracted from human granulosa (lane 1, used as a positive control) and human spermatozoa isolated from the $95 \%$ PureSperm fraction (lanes 2-5); $30 \mu \mathrm{g}$ of protein were loaded in each lane. Molecular masses $(\mathrm{kDa})$ are indicated on the left of the blot.

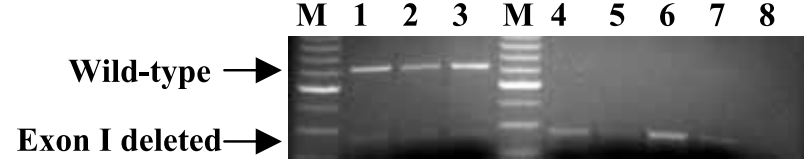
variant

Figure 8 Detection of ER $\alpha$ exon-1-deleted variant mRNA by RT-PCR in human germ cells and human purified spermatozoa. Lanes 1-3: RNA extracted from human germ cells; lanes 4-7: RNA extracted from human spermatozoa isolated from the 95\% PureSperm fraction; lane 8: RNA replaced by distilled water. M, DNA ladder (100 bp ladder). Arrows indicate the PCR products and the expected size of amplified fragments.

another primer that recognised both exon $\mathrm{E}$ and exon F, to look for the expression of this exon-1-truncated transcript. In human germ cells, two bands were obtained (Fig. 8). The 620 bp band corresponded to the wild-type, whereas the lower band (264 bp) was related to the ER $\alpha$ exon-1deleted variant mRNA (Green et al. 1986, GenBank accession No. X03635·1). In human spermatozoa, we amplified only the $264 \mathrm{bp}$ product (Fig. 8). These results were consistent with detection of the $46 \mathrm{kDa}$ protein.

\section{Discussion}

The existence of $\operatorname{ER} \alpha, \operatorname{ER} \beta$ and aromatase in the adult human testis is the subject of numerous studies, but the expression and cellular localisation of ER subtypes is not yet clear. The primary purpose of our study was to look for the expression of aromatase and oestrogen receptors in human germ cells in order to add an alternative view to the conflicting data.

In this study, we detected the expression of aromatase and ER in human germ cells, in terms of both mRNA and protein. In ejaculated spermatozoa, we demonstrated the presence of both mRNA and protein ER $\alpha$, whereas in the case of $\operatorname{ER} \beta$ we detected the presence of only mRNA.

In mammals, it is now well established that germ cells represent a new source of oestrogens (Nitta et al. 1993, Tsubota et al. 1993, Levallet et al. 1998, Carreau 2001). In adult human testis, aromatase has been immunolocalised to the cytoplasm surrounding elongated spermatids (Turner et al. 2002) and in the cytoplasmic droplet of ejaculated spermatozoa (Rago et al. 2003), but was absent from other germ cells (Turner et al. 2002). 
The presence of ER in germ cells is also well documented, and most of the studies favoured ER $\beta$ as the predominant form in mammalian germ cells (Saunders et al. 2002, Zhou et al. 2002). In human germ cells, the presence of both types of ER is controversial. Although Pelletier \& El-Alfy (2000) have reported no tubular staining, other authors (Enmark et al. 1997, Mäkinen et al. 2001, Saunders et al. 2002) have immunolocalised $\operatorname{ER} \beta$ to human germ cells. Using fixed human testes and Western blot analysis, Saunders et al. (2001) and Mäkinen et al. (2001) were unable to demonstrate the presence of ER $\alpha$ in testis, whereas Pentikaïnen et al. (2000), who performed immunohistochemistry on squash preparations of segments of human seminiferous tubules, demonstrated the existence of $\mathrm{ER} \alpha$ protein. The discrepancies between these studies could be explained by the different methodologies used.

The human germ cells used were obtained from semen samples with excessive shedding of immature germ cells $(>20 \%)$. It has been shown that germ cells constitute the main component of non-sperm cells in semen from men without infections (Auroux et al. 1985, Jassim \& Festenstein 1987, Smith et al. 1989). Moreover, it has also been reported that purified immature germ cells isolated from semen samples could be useful for diagnostic and research purposes (Gandini et al. 1999). However, these cells have not been isolated from testis and could reflect a defect of spermatogenesis.

We visualised the aromatase as a single band of $49 \mathrm{kDa}$, as we have already reported for human ejaculated spermatozoa (Lambard et al. 2003). The small variation in aromatase molecular mass observed between granulosa cells and human germ cells could be due to the level of glycosylation; however, as already described (Sethumadhavan et al. 1991, Moslemi et al. 1997), glycosylation does not seem to have an impact on the enzymatic activity.

Using Western blot, we detected two bands for $\mathrm{ER} \beta$, which could correspond to use of alternative start sites in the mRNA. In human ejaculated spermatozoa, we detected only the ER $\beta$ mRNA and not the protein. This result is in agreement with the findings of Saunders et al. (2001, 2002). This transcript may represent some remnants of spermatogenesis or spermiogenesis. The putative existence of translationally repressed mRNAs in spermatozoa has been reported, and they could also represent a paternal contribution for the initiation of the first zygote division (Siffroi \& Dadoune 2001).

Using a monoclonal antibody specific to the C-terminus of full-length of ER $\alpha$, we detected two bands in human germ cells: one at the expected size $(66 \mathrm{kDa})$ and a weaker one at $46 \mathrm{kDa}$. This latest form has also been identified in several cellular types such as endothelial cells (Figtree et al. 2003) or osteoblasts (Denger et al. 2001), and could correspond to an isoform of $\mathrm{ER} \alpha$ that lacks exon 1. That isoform is a powerful inhibitor of the $66 \mathrm{kDa}$ $\mathrm{ER} \alpha$ when they are coexpressed in the same cell (Flouriot et al. 2000), but the same variant has also been implicated in the rapid oestrogen signalling pathway (Figtree et al. 2003), particularly by mediating acute activation of endothelial nitric oxide synthase in response to oestrogen stimulation (Li et al. 2003). The $46 \mathrm{kDa}$ protein is the only form identified in spermatozoa. This result is consistent with those of several studies showing the presence of specific binding sites for $17 \beta$-oestradiol on the human sperm membrane (Cheng et al. 1981, Durkee et al. 1998). It has been demonstrated previously that oestradiol increased motility, oxidative metabolism, longevity of spermatozoa and oocyte penetration (Idaomar et al. 1989). Recently, it has been shown that oestradiol and phytoestrogens improve mouse sperm capacitation (Adeoya-Osiguwa et al. 2003). Thus oestrogens may act via a membrane oestrogen-binding protein, to exert a rapid effect. However, this putative receptor is not yet well identified and some additional studies are necessary to clarify the protein and the pathways involved.

Our data showed the existence of another alternatively spliced isoform of $\mathrm{ER} \alpha$ in human germ cells; this isoform lacks a region that exactly corresponds to exon 4. This variant has been identified in human breast cancer cell lines and in brain (Pfeffer et al. 1993, Skipper et al. 1993); it does not possess the hinge domain and lacks a part of the ligand-binding domain. The role of the putative protein is unknown, but some data suggest that this isoform either could have a cellular distribution and oestrogen-binding affinity different from the normal receptor (Pfeffer et al. 1993) or could act as a ligand-independent transcription factor (Skipper et al. 1993). Indeed, by Western blot analysis we did not find any size variant corresponding to the $54 \mathrm{kDa}$ protein in our cell preparations. 
The role of oestrogens in male reproduction is now better understood and is supported by many studies. Firstly, the administration of an aromatase inhibitor in rat (Tsutsumi et al. 1987) and monkey (Shetty et al. 1998) leads to a reduction in numbers of round and elongated spermatids. Secondly, aromatase-deficient (ArKO) mice became infertile as a result of an impairment of spermiogenesis associated with a decrease in sperm motility and an inability to fertilise oocytes (Robertson et al. 1999, 2001). Six cases of oestrogen deficiency caused by an inactivating mutation of the Cyp19 gene have been described (Morishima et al. 1995, Carani et al. 1997, Deladoey et al. 1999, Murata et al. 2001, Herrman et al. 2002, Kottler et al. 2002); analysis of spermatic parameters in three patients revealed a decreased motility (Carani et al. 1997, Herrman et al. 2002, Kottler et al. 2002). Thirdly, $\alpha \mathrm{ERKO}$ mice are infertile because of an alteration in fluid reabsorption in the proximal parts of the epididymis (Hess et al. 1997). An inactivating mutation of the ER $\alpha$ gene in man has been reported by Smith et al. (1994); the number of spermatozoa was in the normal range, although their viability was diminished. In contrast, $\beta E R K O$ mice do not have altered spermatogenesis (Krege et al. 1998).

Oestrogens could influence the development of germ cells at several levels: stem cell number and spermatid maturation. Indeed, the proliferation of rat gonocytes is induced by $17 \beta$-oestradiol $(\mathrm{Li}$ et al. 1997). Moreover, male rats treated perinatally with an aromatase inhibitor showed a decrease in the number of spermatozoa in the testis (Gerardin et al. 2002). Hypogonadal mice, in which germ cell development never progresses beyond the pachytene stage, developed elongated spermatids after treatment with oestradiol (Ebling et al. 2000). In addition, in bank voles treated with oestradiol during the resting season, a recrudescence of spermatogenesis has been demonstrated (Bilinska et al. 2002). The same observations were recorded in hamsters kept under short-day photoperiod and treated with oestradiol (Pak et al. 2002). Indeed, it has been shown that the recrudescence of spermatogenesis in rodents and some steps in spermiogenesis are under the control of oestrogen (for reviews see O'Donnell et al. 2001, Carreau et al. 2002). Oestradiol has also been proposed as a germ cell survival factor in the human testis (Pentikaïnen et al. 2000).
In conclusion, this study was undertaken to look for the expression of aromatase and oestrogen receptors in human immature germ cells and ejaculated spermatozoa. We demonstrated the existence of aromatase and several $\operatorname{ER} \beta$ and $\operatorname{ER} \alpha$ isoforms, as both mRNA and proteins, in human germ cells. However, the roles of oestrogens in human testis are not clearly defined, and further studies are required to elucidate the mechanism of action of oestrogen, in terms of both genomic and non-genomic pathways.

\section{References}

Adeoya-Osiguwa SA, Markoulaki S, Pocock V, Millingan SR \& Fraser LR 2003 17ß-Estradiol and environmental estrogens significantly affect mammalian sperm function. Human Reproduction $18100-107$

Albanesi C, Geremia R, Giorgio M, Dolci S \& Sette C 1996 A celland developmental stage-specific promoter drives the expression of a truncated c-kit protein during mouse spermatid elongation. Development 122 1291-1302.

Aquila S, Sisci D, Gentile M, Middea E, Siciliano L \& Ando S 2002 Human ejaculated spermatozoa contain active P450 aromatase. Fournal of Clinical Endocrinology and Metabolism 87 3385-3390.

Auroux M, Collin G \& Couvillers ML 1985 Do non-spermatozoal cells mainly stem from spermiogenesis? Study of 106 fertile and 102 subfertile men. Archives of Andrology 14 73-80.

Bilinska B, Gancarczyk M, Kotula-Balak M, Carreau S \& Slomczynska M 2002 Effect of 17 beta-estradiol on spermatogenesis in immature bank voles. Proceedings of an International Conference: Aromatase 2002 - The new millennium, 26-30 October 2002, Kyoto, Japan.

Bradford MM 1976 A rapid and sensitive method for the quantification of microgram quantities of protein utilizing the principle of protein-dye binding. Analytical Biochemistry $\mathbf{7 2}$ 248-254.

Brodie A, Inskter S \& Yue W 2001 Aromatase expression in the human male. Molecular and Cellular Endocrinology 178 23-28.

Carani C, Qin K, Simoni M, Faustini-Fustini M, Serpente S, Boyd J, Korach KS \& Simpson ER 1997 Effect of testosterone and estradiol in a man with aromatase deficiency. New England Fournal of Medicine 337 91-95.

Carreau S 2001 Germ cells: a new source of estrogens in the male gonad. Molecular and Cellular Endocrinology 178 65-72.

Carreau S, Papadopoulos V \& Drodowsky MA 1988 Stimulation of adult rat Leydig cell aromatase activity by a Sertoli cell factor. Endocrinology 122 1103-1109.

Carreau S, Genissel C, Bilinska B \& Levallet J 1999 Sources of oestrogen in the testis and reproductive tract of the male. International Foumal of Andrology 22 211-223.

Carreau S, Bourguiba S, Lambard S, Galeraud-Denis I, Genissel C, Bilinska B, Benahmed M \& Levallet J 2002 Aromatase expression in male germ cells. Fournal of Steroid Biochemistry and Molecular Biology 79 203-208.

Cheng CY, Boettcher B, Rose RJ, Kay DJ \& Tinneberg HR 1981 The binding of sex steroids to human spermatozoa. An autoradiographic study. International fournal of Andrology 4 1-17.

Chomczynski P \& Sacchi N 1987 Single step method of RNA isolation by acid guanidinium thiocyanate-phenol-chloroform extraction. Analytical Biochemistry 162 156-159. 
Deladoey J, Fluck C, Bex M, Yoshimura N, Hararda N \& Mullis PE 1999 Aromtase deficiency caused by a novel P450 arom gene mutation: impact of absent estrogen production on serum gonadotropin concentration in a boy. Fournal of Clinical Endocrinology and Metabolism 84 4050-4054.

Denger S, Reid G, Kos M, Flouriot G, Parsch D, Brand H, Korach KS, Sonntag-Buck V \& Gannon F 2001 ER $\alpha$ gene expression in human primary osteoblasts: evidence for the expression of two receptor proteins. Molecular Endocrinology 15 2064-2077.

Durkee TJ, Mueller M \& Zinaman M 1998 Identification of estrogen receptor protein and messenger ribonucleic acid in human spermatozoa. American Fournal of Obstetrics and Gynecology 178 1288-1297.

Ebling FJP, Brooks AN, Cronin AS, Ford H \& Kerr JB 2000 Estrogenic induction of spermatogenesis in the hypogonadal mouse. Endocrinology 141 2861-2869.

Enmark E, Pelto-Huikko M, Grandien K, Lagercrantz S, Lagercrantz J, Fried G, Nordenskjöld M \& Gustafson JA 1997 Human oestrogen receptor $\beta$-gene structure, chromosomal localization, and expression pattern. Fournal of Clinical Endocrinology and Metabolism 82 4258-4265.

Figtree GA, McDonald D, Watkins H \& Channon KM 2003 Truncated estrogen receptor $\alpha 46 \mathrm{kDa}$ isoform in human endothelial cells. Relationship to acute activation of nitric oxide synthase. Circulation 107 120-126.

Flouriot G, Brand H, Denger S, Metivier R, Kos M, Reid G, Sonntag-Buck V \& Gannon F 2000 Identification of a new isoform of the human estrogen receptor-alpha (hER- $\alpha$ ) that is encoded by distinct transcripts and that is able to repress hER- $\alpha$ activation function 1. EMBO Joumal 19 4688-4700.

Gandini L, Lenzi A, Lombardo F, Pacifici R \& Dondero F 1999 Immature germ cells separation using a modified discontinuous Percoll gradient technique in human semen. Human Reproduction $\mathbf{1 4}$ 1022-1027.

Gerardin DCC \& Pereira OCM 2002 Reproductive changes in male rats treated perinatally with an aromatase inhibitor. Pharmacology, Biochemistry and Behavior 71 309-313.

Goyal HO, Bartol FF, Wiley AA \& Neff CW 1997

Immunolocalization of receptors for androgen and estrogen in male caprine reproductive tissues: unique distribution of estrogen receptors in efferent ductile epithelium. Biology of Reproduction $\mathbf{5 6}$ 90-101.

Green S, Walter P, Kumar V, Krust A, Bornert JM, Argos P \& Chambon P 1986 Human oestrogen receptor cDNA: sequence, expression and homology to v-erb-A. Nature 320 134-139.

Herrman BL, Saller B, Janssen OE, Gocke P, Bockisch A, Sperling H, Mann K \& Broecker M 2002 Impact of estrogen replacement therapy in a male with congenital aromatase deficiency caused by a novel mutation in the CYP19 gene. Fournal of Clinical Endocrinology and Metabolism 87 5476-5484.

Hess RA, Bunick D, Lee KH, Bahr J, Taylor JA \& Korach KS 1997 A role for oestrogens in the male reproductive system. Nature $\mathbf{3 9 0}$ 509-512.

Hillier SG, Anderson RA, Williams ARW \& Tetsuka M 1998 Expression of oestrogen receptor $\alpha$ and $\beta$ in cultured human ovarian surface epithelial cells. Molecular Human Reproduction 4 811-815.

Hirata S, Shoda T, Kato J \& Hoshi K 2003 Isoform/variant mRNAs for sex steroid hormone receptors in humans. Trends in Endocrinology and Metabolism 14 124-129.

Idaomar M, Guerin JF, Lornage J \& Czyba JC 1989 Stimulation of motility and energy metabolism of spermatozoa from asthenospermic patients by 17 beta-estradiol. Archives of Andrology 22 197-202.

Janulis L, Bahr JM, Hess RA, Janssen S, Osawa Y \& Bunick D 1998 Rat testicular germ cells and epididymal sperm contain active P450 aromatase. Fournal of Andrology 19 65-71.
Jassim A \& Festenstein H 1987 Immunological and morphological characterisation of nucleated cells other than sperm in semen of oligospermic donors. Fournal of Reproduction and Immunology 11 77-89.

Kottler ML, Pura M, Mittre H \& Carreau S 2002 Clinical findings in an adult man with a novel mutation in the aromatase gene. Proceedings of an International Conference: Aromatase 2002 - The new millennium, 26-30 October 2002, Kyoto, Japan.

Krege JH, Hodgin JB, Couse JF, Enmark E, Warner M, Mahler JF, Sar M, Korach KS, Gustafsson JA \& Smithies O 1998 Generation and reproductive phenotypes of mice lacking estrogen receptor $\beta$. PNAS 95 15677-15682.

Kuiper GGJM, Enmark E, Pelto-Huikko M, Nilsson S \& Gustafsson JA 1996 Cloning of a novel estrogen receptor expressed in rat prostate and ovary. PNAS 93 5925-5930.

Lambard S, Galeraud-Denis I, Bouraïma H, Bourguiba S, Chocat A \& Carreau S 2003 Expression of aromatase in human ejaculated spermatozoa: a putative marker of motility. Molecular Human Reproduction 9 117-124.

Levallet J, Bilinska B, Mittre H, Genissel C, Fresnel J \& Carreau S 1998 Expression and immunolocalization of functional cytochrome P450 aromatase in rat testicular cells. Biology of Reproduction 58 919-926.

Li H, Papadopoulos V, Vidic B, Dym D \& Cully M 1997 Regulation of rat testis gonocyte proliferation by platelet-derived growth factor and estradiol: identification of signaling mechanisms involved. Endocrinology 138 1289-1298.

Li L, Haynes MP \& Bender JR 2003 Plasma membrane localization and function of the estrogen receptor $\alpha$ variant (ER46) in human endothelial cells. PNAS 100 4807-4812.

Luconi M, Muratori M, Forti G \& Baldi E 1999 Identification and characterization of a novel functional estrogen receptor on human sperm membrane that interferes with progesterone effects. Foumal of Clinical Endocrinology and Metabolism 84 1670-1678.

Mäkinen S, Mäkela S, Zhang WH, Warner M, Rosenlund B, Salmi S, Hovatta O \& Gustafsson JA 2001 Localization of oestrogen receptors alpha and beta in human testis. Molecular Human Reproduction 7 497-503.

Morishima A, Grumbach MM, Simpson ER, Fisher C \& Qin K 1995 Aromatase deficiency in male and female siblings caused by a novel mutation and the physiological role of estrogens. Fournal of Clinical Endocrinology and Metabolism 80 3689-3698.

Moslemi S, Vibet A, Papadopoulos V, Camoin L, Silberzahn P \& Gaillard JL 1997 Purification and characterization of equine testicular cytochrome P-450 aromatase: comparison with the human enzyme. Comparative Biochemistry and Physiology 118 217-227.

Mowa CN \& Iwanaga T 2001 Expression of estrogen receptor- $\alpha$ and $-\beta$ mRNAs in the male reproductive system of the rat as revealed by in situ hybridization. Fournal of Molecular Endocrinology 26 $165-174$.

Murata Y, Gong E, Clyne C, Gong E, Simpson ER \& Maffei L 2001 Point mutation in the GYP19 gene and its consequence. Proceedings of the 83rd Annual Meeting of the Endocrine Society, Denver, 20-23 June 2001. Abstract.

Nitta H, Bunick D, Hess RA, Janulis L, Newton SC, Osawa Y, Shizuta Y, Toda K \& Bahr JM 1993 Germ cells of the mouse testis express P450 aromatase. Endocrinology 132 1396-1401.

O'Donnell L, Robertson KM, Jones ME \& Simpson ER 2001 Estrogen and spermatogenesis. Endocrine Review 22 289-318.

Pak TR, Lynch R \& Tsai PS 2002 estrogen accelerates gonadal recrudescence in photo-regressed male Siberian hamsters. Endocrinology 143 4131-4134.

Papadopoulos S, Carreau S, Szerman-Joly E, Drodowsky MA, Dehennin L \& Scholler R 1986 Rat testis 17 beta-estradiol: identification by gas chromatography-mass spectrometry and 
age-related cellular distribution. Fournal of Steroid and Biochemistry $\mathbf{2 4}$ 1211-1216.

Payne AH, Kelch RP, Musich SS \& Halpern ME 1976 Intratesticular site of aromatization in the human. Fournal of Clinical Endocrinology and Metabolism 114 1081-1087.

Pelletier G \& El-Alfy M 2000 Immunocytochemical localization of estrogen receptors $\alpha$ and $\beta$ in the human reproductive organs. Fournal of Clinical Endocrinology and Metabolism 85 4835-4840.

Pentikaïnen V, Rekkilä K, Suomalainen L, Parvinen M \& Dunkel L 2000 Estradiol acts as a germ cell survival factor in the human testis in vitro. Fournal of Clinical Endocrinology and Metabolism $\mathbf{8 5}$ 2057-2067.

Pfeffer U, Fecarotta E, Castagnetta L \& Vidali G 1993 Estrogen receptor variant messenger RNA lacking exon 4 in estrogen-responsive human breast cancer cell lines. Cancer Research $15741-743$

Rago V, Bilinska B, Palma A, Ando S \& Carpino A 2003 Evidence of aromatase localization in cytoplasmic droplet of human immature ejaculated spermatozoa. Folia Histochemica et Cytobiologica $4123-27$.

Ralph JS, Thomas ML, Morton CC \& Trowbridge IS 1987 Structural variants of human T200 glycoprotein (leukocyte-common antigen). EMBO fournal 6 1251-1257.

Robertson KM, O'Donnell L, Jones ME, Meachem SJ, Boon WC, Fisher CR, Graves KH, McLachlan RI \& Simpson ER 1999 Impairment of spermatogenesis in mice lacking a functional aromatase (cyp 19) gene. PNAS 96 7986-7991.

Robertson KM, Simpson ER, Lacham-Kaplan O \& Jones MEE 2001 Characterization of the fertility of male aromatase knockout mice. Journal of Andrology 22 825-830.

de los Santos MJ, Anderson DJ, Racowsky C, Simon C \& Hill JA 1998 Expression of interleukin-1 system genes in human gametes. Biology of Reproduction 59 1419-1424.

Saunders PTK, Fisher JS, Sharpe RM \& Millar MR 1998 Expression of estrogen receptor beta $(\mathrm{R} \beta)$ occurs in multiple cell types, including some germ cells, in the rat testis. Fournal of Endocrinology 156 R13-R17.

Saunders PTK, Sharpe RM, Williams K, Macpherson S, Urquart H, Irvine DS \& Millar MR 2001 Differential expression of oestrogen receptor $\alpha$ and $\beta$ proteins in the testis and male reproductive system of human and non-human primates. Molecular Human Reproduction 7 227-236.

Saunders PTK, Millar MR, MacPherson S, Irvine DS, Groome NG, Evans LR, Sharpe RM \& Scobie GA 2002 ER $\beta 1$ and the ER $\beta 2$ splice variant $(\mathrm{ER} \beta \mathrm{cx} / \beta 2)$ are expressed in distinct cell populations in the adult human testis. Fournal of Clinical Endocrinology and Metabolism 87 2706-2715.

Sethumadhavan K, Bellino FL \& Thotakura NR 1991 Estrogen synthetase (aromatase). The cytochrome P-450 component of the human placental enzyme is a glycoprotein. Molecular and Cellular Endocrinology 78 25-32.

Shetty G, Krishnamurthy H, Krishnamurthy HN, Bhatnagar AS \& Moudgal NR 1998 Effect of long-term treatment with aromatase inhibitor on testicular function of adult male bonnet monkeys ( $M$. radiata). Steroids $63414-420$.

Siffroi JP \& Dadoune JP 2001 Accumulation of transcripts in the mature human sperm nucleus: implication of the haploid genome in a functional role. Italian Journal of Anatomy and Embryology 106 189-197.

Simpson ER, Clyne C, Rubin G, Boon WC, Roberston K, Britt K, Speed C \& Jones M 2002 Aromatase - a brief overview. Annual Revieres of Physiology 64 93-127.

Skipper JK, Young LJ, Bergeron JM, Tetzlaff MT, Osborn CT \& Crews D 1993 Identification of an isoform of the estrogen receptor messenger RNA lacking exon four and present in the brain. PNAS $907172-7175$.

Smith DC, Barratt CL \& Williams MA 1989 The characterisation of non-sperm cells in the ejaculate of fertile men using transmission electron microscopy. Andrologia 21 319-333.

Smith EP, Boyd J, Franck GR, Takahashi H, Cohen RM, Specker B, Willians TC, Lubahn DB \& Korach KS 1994 Estrogen resistance caused by a mutation in the estrogen-receptor gene in a man. New England Journal of Medicine 331 1056-1061.

Teyssier-Le Discorde M, Prost S, Nandrot E \& Kirszenbaum M 1999 Spatial and temporal mapping of c-kit and its ligand, stem cell factor expression during human embryonic haemopoiesis. British Fournal of Haematology 107 247-253.

Tsubota T, Nitta H, Osawa Y, Mason I, Kita I, Tiba T \& Bahr JM 1993 Immunolocalization of steroidogenic enzymes, P450 scc, 33-HSD, P450 c17 and P450 arom in the Hokkaido brown bear. General and Comparative Endocrinology 92 439-444.

Tsutsumi I, Fugimori F, Nakamura Mathuu JP, Ono T \& Dizerega GS 1987 Disruption of seminiferous epithelial function in the rat by ovarian protein. Biology of Reproduction 36 451-461.

Turner KJ, Macpherson S, Millar MR, McNeilly AS, Williams K, Cranfield M, Groome NP, Sharpe RM, Fraser HM \& Saunders PTK 2002 Development and validation of a new monoclonal antibody to mammalian aromatase. Foumal of Endocrinology 172 21-30.

Van Pelt AMM, De Rooij DG, Van der Burg B, Van der Saag PT, Gustafsson JA \& Kuiper GGJM 1999 Ontogeny of estrogen receptor- $\beta$ expression in rat testis. Endocrinology $140478-483$.

World Health Organisation 1999 WHO laboratory manual for the examination of human semen and sperm-cervical mucus interaction. Cambridge University Press.

Zhou Q, Nie R, Prins GS, Saunders PTK, Katzenellenbogen BS \& Hess RA 2002 Localization of androgen and estrogen receptors in adult male mouse reproductive tract. Fournal of Andrology $\mathbf{2 3}$ 870-881.

Received in final form 15 September 2003 Accepted 10 November 2003 